\title{
Pengaruh Status Penguasaan Lahan Terhadap Produksi Padi Sawah Tadah Hujan di Kabupaten Banyumas
}

\author{
Rifki Andi Novia1* \\ Ratna Satriani ${ }^{2}$ \\ 1), 2) Jurusan Agribisnis, Fakultas Pertanian, Universitas Jenderal Soedirman \\ *email : rifkiandinovia@unsoed.ac.id \\ Diterima: Januari 2020, Disetujui; Maret 2020, Dipublish: April 2020
}

\begin{abstract}
Abstrak
Penelitian ini bertujuan untuk mengetahui pengaruh status penguasaan lahan pertanian terhadap produksi padi sawah tadah hujan di Kabupaten Banyumas. Salah satu faktor produksi paling penting yang berpengaruh terhadap produksi padi sawah tadah hujan adalah lahan yang digunakan. Penelitian ini menggunakan metode survei dengan cara mengambil data primer dan data sekunder. Data primer diperoleh melalui daftar pertanyaan yang telah disiapkan, sedangkan data sekunder diperoleh dari instansi yang terkait. Metode pengambilan sampel dilakukan dengan stratified random sampling. Masing - masing strata ditarik sampel dengan jumlah sampel penelitian keseluruhan sebanyak 50 petani responden. Analisis data yang digunakan dalam penelitian ini menggunakan analisis varians satu arah (One-way ANOVA). Hasil penelitian ini menunjukkan bahwa jumlah produksi padi sawah tadah hujan di Kabupaten Banyumas menunjukkan perbedaan yang signifikan antara petani bukan pemilik dengan petani pemilik lahan. Petani bukan pemilik mendapatkan rata-rata hasil produksi yang lebih besar daripada petani pemilik lahan sawah tadah hujan di Kabupaten Banyumas.
\end{abstract}

Kata kunci : status, lahan, produksi, tadah hujan.

\begin{abstract}
This study aimed to determine the effect of agricultural land tenure status on rainfed lowland rice production in Banyumas Regency. One of the most important factors of production affecting the production of rainfed lowland rice is the land used. This study used survey method by taking primary data and secondary data. Primary data obtained through a list of questions that have been prepared, while secondary data obtained from the relevant agencies. The sampling method is carried out by stratified random sampling. Each stratum of the sample is drawn with a total sample of 50 farmer respondents. Data were analyzed used one-way analysis of variance (One-way ANOVA). The results of this study indicated that the amount of rainfed lowland rice production in Banyumas District showed significant difference between farmers who were not owners and farmers who own land. Non-owner farmers get an average production yield greater than those of farmers who own rainfed lowland rice in Banyumas Regency.
\end{abstract}

Keywords: status, land tenure, production, rainfed lowland.

\section{PENDAHULUAN}

Lahan sebagai faktor produksi alam merupakan bagian yang sangat menentukan dalam keberhasilan usahatani. Lahan memiliki sejumlah karakteristik yang unik dan tidak ditemukan dalam faktor produksi lain. Karateristik faktor produksi lahan inilah yang mempengaruhi bagaimana kegiatan usahatani harus dikelola petani, sehingga akan mendapatkan hasil produksi yang maksimal. 
Menurut Kay, R.D., dkk (2004), faktor produksi lahan merupakan faktor produksi yang bersifat permanen, sehingga tidak mengalami penyusutan (depreciation) walau digunakan berapapun lamanya. Penggunaan faktor produksi lahan yang kurang tepat sehingga kesuburan lahan akan menurun, hanya akan mengurangi kualitas lahan. Namun, pengurangan kualitas tersebut dapat dikembalikan seperti semula melalui pemupukan dan langkah konservasi yang tepat, sehingga kualitas dan kesuburan lahan akan tetap terjaga, bahkan dapat lebih ditingkatkan.

Salah satu karakteristik unik lain dari faktor produksi lahan adalah terkait dengan status penguasaan lahan. Dalam penelitian Winarso, B. (2012), status penguasaan lahan secara umum dikelompokkan ke dalam 2 kelompok besar, yaitu : (1) Lahan Hak Milik dan (2) Lahan Bukan Milik. Menurut Undang - Undang Pokok Agraria Tahun 1960, yang dimaksud dengan penguasaan hak milik lahan adalah kepemilikian turun temurun yang dapat dimiliki seseorang atas sebidang lahan, baik yang berasal dari warisan, pembelian atau hibah dari orang lain. Sedangkan penguasaan Lahan Bukan Milik dapat dibagi menjadi lima jenis, yaitu sewa, sakap (bagi hasil), gadai, numpang dan lahan milik adat. Penguasaan lahan bukan milik merupakan bentuk penguasaan sementara, karena di dalamnya terjadi pengalihan hak garap dari pemilik lahan ke orang lain.
Adanya penguasaan lahan bukan milik seperti lahan sewa dan lahan gadai pada dasarnya disebabkan adanya dorongan ekonomi yang berasal dari petani. Hal ini sejalan dengan penelitian Manatar, MP. dkk (2017) bahwa status penguasaan lahan mempengaruhi rata-rata pendapatan yang diterima oleh petani padi sawah. Rata-rata pendapatan yang paling tinggi adalah petani dengan status penguasaan lahan sewa. Dalam penelitian tersebut juga disarankan bahwa petani yang ingin mengusahakan tingkat pendapatan yang tinggi sebaiknya menggunakan teknik pengolahan lahan petani sewa agar lebih menguntungkan.

Dalam penelitian Mudakir (2011) juga dijelaskan status penguasaan lahan yang berbeda akan menentukan tingkat keragaman usahatani, dalam hal ini meliputi tingkat produktivitas lahan dan distribusi pendapatan yang berlainan. Selain itu, dalam penelitian Tahir, AG (2011), status penguasaan lahan dengan sistem bagi hasil bernilai positif dan berpengaruh nyata terhadap produksi serta memberikan kontribusi negatif terhadap resiko. Hal ini berarti bahwa status penguasaan lahan dengan sistem bagi hasil (lahan bukan milik) menjadikan petani lebih berhati-hati dalam mengelola usahataninya.

Kabupaten

Banyumas merupakan salah satu kabupaten di Jawa Tengah, dimana sebagian besar masyarakatnya bekerja di sektor pertanian. Sistem pengairan lahan 
persawahan di Kabupaten Banyumas beragam, tidak seluruhnya dilalui oleh sistem irigasi teknis. Untuk wilayahwilayah di Kabupaten Banyumas dengan topografi bukan dataran yang rata atau berupa perbukitan, maka sistem irigasinya berupa tadah hujan. Status penguasaan lahan pertanian masyarakat di kabupaten ini pun beragam, dari lahan hak milik, lahan sewa, lahan sakap (bagi hasil), lahan gadai, dsb. Namun dalam penelitian ini, status penguasaan lahan pertanian akan disederhanakan menurut Winarso, B (2012), yakni lahan hak milik dan lahan bukan milik. Lahan hak milik petani padi sawah tadah hujan di Kabupaten Banyumas didapatkan dari kepemilikan turun temurun atau warisan dan pembelian, yang diperkuat oleh bukti hukum tertulis berupa sertifikat tanah yang sah. Lahan bukan milik petani padi sawah tadah hujan di Kabupaten Banyumas terbanyak didapatkan dengan cara sewa dan sakap (bagi hasil) dengan pemilik lahan.

Berdasarkan uraian latar belakang, yang menjadi masalah dalam penelitian ini adalah bagaimana pengaruh status penguasaan lahan pertanian terhadap produksi padi sawah tadah hujan di Kabupaten Banyumas. Tujuan penelitian untuk mengetahui pengaruh status penguasaan lahan pertanian terhadap produksi, serta bagaimana penggunaan faktor produksi antara petani dengan status penguasaan lahan yang berbeda pada padi sawah tadah hujan di Kabupaten Banyumas.

\section{METODOLOGI PENELITIAN}

Penelitian ini dilakukan di 2 Kecamatan di Kabupaten Banyumas, yakni di Kecamatan Lumbir dan Kecamatan Gumelar, dimana sebagian besar lahan persawahannya menggunakan sistem irigasi tadah hujan (Banyumas Dalam Angka, 2011). Waktu penelitian dilakukan pada Musim Tanam II (April September) Tahun 2018.

Penelitian ini menggunakan metode survei dengan data primer diperoleh melalui daftar pertanyaan yang telah disiapkan, sedangkan data sekunder diperoleh dari instansi terkait. Metode pengambilan sampel dilakukan dengan stratified random sampling. Masing - masing strata ditarik dengan jumlah sampel penelitian sebanyak 50 petani yang dapat mewakili keseluruhan populasi yang ada. Sebaran sampel petani ditunjukkan pada Tabel 1. berikut.

Tabel 1. Sebaran Petani Responden Berdasarkan Status Penguasaan Lahan

\begin{tabular}{|c|c|c|}
\hline $\begin{array}{c}\text { Kategori } \\
\text { Petani }\end{array}$ & $\begin{array}{l}\text { Jumlah } \\
\text { (Orang) }\end{array}$ & Persentase \\
\hline Petani Pemilik & 25 & $50 \%$ \\
\hline $\begin{array}{l}\text { Petani Bukan } \\
\text { Pemilik }\end{array}$ & 25 & $50 \%$ \\
\hline Jumlah & 50 & $100 \%$ \\
\hline
\end{tabular}

Sumber : Diolah dari Data Primer, 2018.

\section{Analisis Data}

Analisis data yang digunakan dalam penelitian ini menggunakan analisis varians satu arah (One-way ANOVA), dengan aplikasi Microsoft Excel 2013. Analisis varians memiliki keunggulan dalam hal kemampuan 
untuk membandingkan antarvariabel. Pada pengujian ANOVA dengan menggunakan satu faktor, dapat diuji apakah ada perbedaan nyata rata-rata produksi, antara status penguasaan lahan hak milik dengan status penguasaan lahan bukan milik. Hipotesis penelitian yakni rata-rata produksi petani dengan status penguasaan lahan hak milik dengan status penguasaan lahan bukan milik tidaklah sama. Secara statistik, hipotesis tersebut dapat dirumuskan sebagai berikut :

$$
\begin{array}{ll}
H_{0}: & \mu_{1}=\mu_{2} \\
H_{1}: & \mu_{1} \neq \mu_{2}
\end{array}
$$

Keterangan :

$\mu_{1}$ : rata-rata produksi lahan hak milik

$\mu_{1}$ : rata-rata produksi lahan bukan milik

\begin{tabular}{|c|c|c|}
\hline \multirow[b]{2}{*}{ Responden } & \multicolumn{2}{|c|}{ Status Penguasaan Lahan } \\
\hline & $\begin{array}{c}\text { Milik } \\
\text { Sendiri }\end{array}$ & $\begin{array}{c}\text { Bukan Milik } \\
\text { Sendiri }\end{array}$ \\
\hline Petani 1 & $Y_{11}$ & $Y_{12}$ \\
\hline Petani 2 & $Y_{21}$ & $Y_{22}$ \\
\hline Petani 3 & $Y_{31}$ & $Y_{32}$ \\
\hline$\ldots$ & $\cdots$ & $\ldots$ \\
\hline Petani N & $Y_{n 1}$ & $Y_{n 2}$ \\
\hline Jumlah & Y.1 & Y.2 \\
\hline
\end{tabular}

Tabel 2. Analisis Penelitian

Sumber : Gomez, KA. 1995.

Langkah - langkah :

1. Faktor Koreksi (FK)

$$
\mathrm{FK}=\frac{G^{2}}{n}=\frac{\sum Y_{i j}{ }^{2}}{t \cdot r}
$$

2. Jumlah Kuadrat Umum (JKU)

$$
\begin{aligned}
\mathrm{JKU}= & \sum_{i=1}^{n} Y_{i j}{ }^{2}-\mathrm{FK} \\
= & \left(Y_{11}\right)^{2}+\left(Y_{12}\right)^{2}+\left(Y_{13}\right)^{2}+\cdots \\
& +\left(Y_{i j}\right)^{2}-\mathrm{FK}
\end{aligned}
$$

3. Jumlah Kuadrat Perlakuan (JKP)

$$
\begin{aligned}
\mathrm{JKP} & =\frac{\sum_{i=1}^{t} Y_{i}^{2}}{r_{i}}-\mathrm{FK} \\
& =\frac{(Y .1)^{2}}{r_{1}}+\frac{(Y .2)^{2}}{r_{2}}-\mathrm{FK}
\end{aligned}
$$

4. Jumlah Kuadrat Galat (JKG)

$$
\mathrm{JKG}=\mathrm{JKU}-\mathrm{JKP}
$$

5. Kuadrat Tengah Perlakuan (KTP)

$$
\begin{array}{r}
\text { KTP }=\frac{\text { JKP }}{\text { d. b. Perlakuan }} \\
=\frac{\text { JKP }}{t-1}
\end{array}
$$

6. Kuadrat Tengah Galat (KTG)

$$
\mathrm{KTG}=\frac{\mathrm{JKG}}{\text { d. b. Galat }}=\frac{\mathrm{JKP}}{t-1}
$$

7. F-Hitung Perlakuan

$$
\mathrm{F}_{\text {Hitung }}=\frac{\mathrm{KTP}}{\mathrm{KTG}}
$$

(Gomez, KA. 1995)

Dari perhitungan analisis uji ANOVA tersebut maka didapatkan nilai $\mathrm{F}$ Hitung yang selanjutnya dibandingkan dengan F-Tabel.

- Jika F-Hitung > F-Tabel ; maka $\mathrm{H}_{0}$ ditolak dan $\mathrm{H}_{1}$ diterima.

- Jika F-Hitung < F-Tabel ; maka $\mathrm{H}_{0}$ diterima dan $\mathrm{H}_{1}$ ditolak.

\section{HASIL DAN PEMBAHASAN \\ Karakteristik Petani Responden}

Karakteristik petani responden digunakan untuk melihat latar belakang sosial ekonomi petani. Karateristik berupa umur petani, tingkat pendidikan, jumlah anggota keluarga dan pengalaman usahatani dapat dilihat pada gambar berikut ini. 


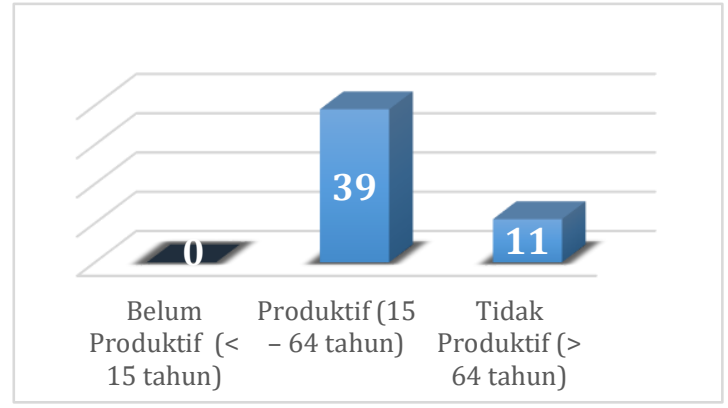

Gambar 1. Sebaran Petani Responden Berda-sarkan Kategori Umur Petani.

Sumber : Diolah dari Data Primer, 2018.

Berdasarkan Gambar 1. dapat diketahui bahwa umur petani sawah tadah hujan di Kabupaten Banyumas terbanyak pada kisaran umur produktif, selebihnya merupakan petani yang tergolong sudah tidak produktif dan tidak terdapat petani yang tergolong umur belum produktif. Menurut Eliyatiningsih dan Mayasari, F (2019), umur petani mempengaruhi kemampuan fisik petani dalam melakukan kegiatan usahatani. Umur petani merupakan salah satu faktor yang berhubungan dengan kemampuan kerja petani. Petani usia produktif akan bekerja lebih baik dibandingkan petani usia non produktif.

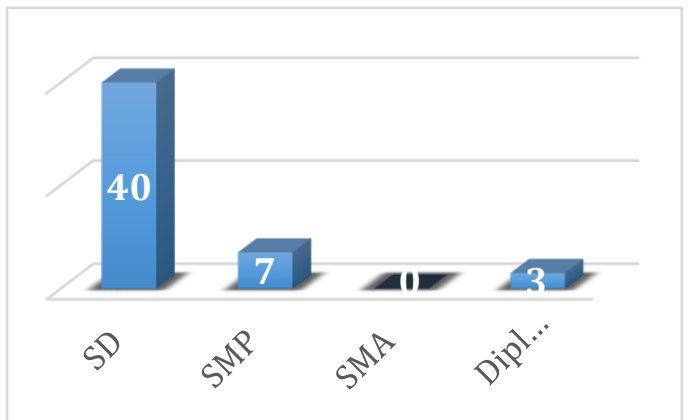

Gambar 2. Sebaran Petani Responden Berdasarkan Tingkat Pendidikan.

Sumber : Diolah dari Data Primer, 2018.
Tingkat pendidikan terbanyak petani responden berpendidikan Sekolah Dasar. Hal ini menunjukkan bahwa sumberdaya manusia petani sawah tadah hujan di Kabupaten Banyumas tergolong rendah. Tingkat pendidikan akan berpengaruh pada tingkat pemahaman dan kemampuan pengelolaan usahatani. Semakin tinggi tingkat pendidikan diharapkan akan semakin cepat pula pemahaman dalam mengatasi permasalahan usahatani yang dikelola, sehingga mendapatkan hasil produksi yang maksimal.

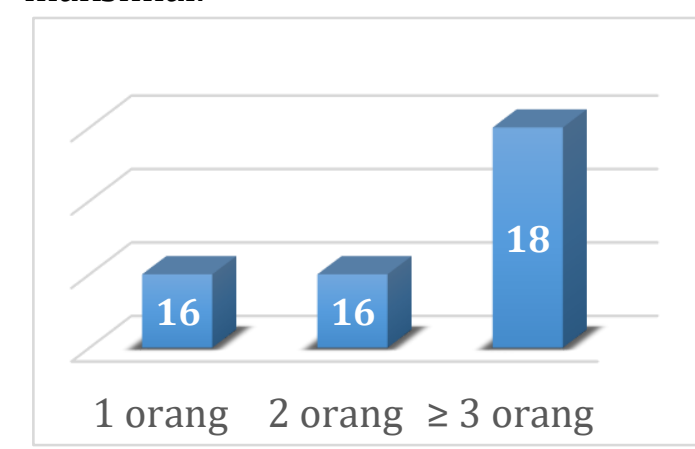

Gambar 3. Sebaran Petani Responden Berdasarkan Anggota Keluarga. Sumber : Diolah dari Data Primer, 2018.

Keluarga merupakan unit masyarakat terkecil dan biasanya terdiri dari beberapa orang. Di masyarakat pedesaan, anggota keluarga yang ada membantu dalam penyediaan tenaga kerja dalam keluarga. Berdasarkan gambar 3 . diketahui bahwa petani responden yang memiliki 1 orang dan 2 orang anggota keluarga sebanyak 64 persen, sedangkan petani responden yang memiliki anggota keluarga berjumlah 3 orang atau lebih yakni sebanyak 36 persen. Hal ini menandakan tingkat ketersediaan tenaga kerja dalam 
keluarga yang sedikit dan kebutuhan tenaga kerja tambahan untuk usahatani dapat digunakan tenaga kerja dari luar keluarga.

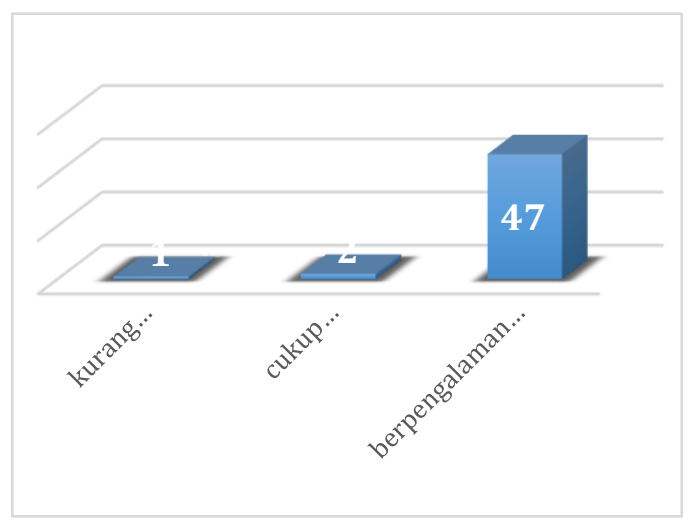

Gambar 4. Sebaran Petani Responden Berda-sarkan Pengalaman Usahatani.

Sumber : Diolah dari Data Primer, 2018.

Pengalaman usahatani dibagi menjadi tiga kategori, menurut Soeharjo dan Patong (1999) dalam Kristono, RJ dan Nadapdap, HJ. (2019), yaitu kurang berpengalaman $(<5$ tahun), cukup berpengalaman (5-10 tahun) dan berpengalaman ( $>10$ tahun). Hasil penelitian diketahui bahwa mayoritas petani responden merupakan petani yang sudah berpengalaman dalam menjalankan usahatani. Semakin banyak pengalaman dalam usahatani, maka akan berdampak pada pengetahuan petani yang semakin baik. Namun semakin banyak pengalaman maka usianya pun semakin berkurang, sehingga berpengaruh pada kemampuan fisik petani (Neonbota SL dan Kune, SJ, 2016).

\section{Faktor Produksi Usahatani Padi}

Dalam aspek faktor produksi usahatani padi, dapat diketahui seberapa besar tingkat penggunaan input produksi dalam menjalankan usahatani padi sawah tadah hujan di Kabupaten Banyumas. Penggunaan faktor produksi, dapat dibedakan antara faktor produksi yang digunakan petani dengan status penguasaan lahan milik dan status penguasaan lahan bukan milik sendiri.

Data penelitian diperoleh bahwa rata-rata penguasaan lahan $(x)$ sebesar $2.084 \mathrm{~m}^{2}$ dengan standar deviasi (Sd) sebesar 1.599. Penentuan kriteria luas lahan yakni dengan cara :

- Luasan $1:<[x-\mathrm{Sd}]$

- Luasan $2:[x-\mathrm{Sd}] \mathrm{s} / \mathrm{d}[x+\mathrm{Sd}]$

- Luasan $3:>[x+\mathrm{Sd}]$

Dari sebaran petani berdasarkan luas lahan produksi diketahui bahwa petani pemilik dan petani bukan pemilik rata-rata menggarap lahan dengan luasan yang relatif sama, yakni antara $480-3.684 \mathrm{~m}^{2}$. Luas lahan petani dengan kedua status penguasaan lahan tersebut secara umum tergolong sempit. Hal tersebut menggambarkan karakteristik lokasi sawah tadah hujan di Kabupaten Banyumas yang memang bukan merupakan hamparan permukaan tanah yang luas, permukaan tanah yang tidak rata dan perbukitan. Selain itu, ada kecenderungan kepemilikan lahan yang semakin menyempit, karena adanya pembagian hak waris secara turun temurun.

Jumlah produksi padi di Kabupaten Banyumas secara 
signifikan dipengaruhi oleh jumlah pupuk Urea, Phonska dan TSP yang digunakan (Novia, RA. 2012). Dari hasil penelitian diketahui bahwa pupuk Urea merupakan pupuk yang paling banyak digunakan petani padi sawah tadah hujan di Kabupaten Banyumas, dan diikuti oleh pupuk Phonska dan TSP. Petani bukan pemilik menggunakan rata-rata jumlah pupuk yang lebih besar per hektarnya dibandingkan petani pemilik, dengan harapan mendapatkan hasil produksi yang lebih banyak.

Penggunaan benih yang tepat dan spesifik lokasi juga merupakan salah satu faktor penentu keberhasilan usahatani padi sawah tadah hujan di Kabupaten Banyumas (Novia, RA. 2012). Benih yang paling banyak ditanam petani adalah benih IR-64, diikuti dengan Mekongga, Hibrida Mapan dan benih lainnya. Rata-rata jumlah benih padi yang disemai oleh petani sebanyak 30,73 $\mathrm{Kg} / \mathrm{Ha}$ untuk petani pemilik dan sebanyak $32,14 \mathrm{Kg} / \mathrm{Ha}$ yang disemai oleh petani bukan pemilik.

Hasil

penelitian menggambarkan bahwa petani menyemai semua jenis benih padi lebih banyak daripada yang sesungguhnya ditanam. Selain sebagai antisipasi kekurangan bibit akibat daya tumbuh benih yang kurang baik, hal tersebut juga dimaksudkan untuk proses penyulaman tanaman. Penyulaman dilakukan apabila daya tumbuh bibit yang sudah ditanam mengalami kendala dalam pertumbuhan, misalkan adanya serangan hama keong mas.

Peranan pestisida terhadap produksi tanaman pangan berbeda dengan faktor produksi lainnya. Pestisida tidak meningkatkan produksi tetapi menyelamatkan produksi dari serangan hama dan penyakit (Damayanti, 2013). Pada lahan sawah tadah hujan di Kabupaten Banyumas, jumlah petisida yang digunakan petani bukan pemilik jauh lebih besar dibandingkan jumlah pestisida yang digunakan petani pemilik. Petani pemilik hanya menggunakan pestisida jika terlihat adanya serangan hama dan penyakit tanaman, sedangkan petani bukan pemilik selalu menggunakan pestisida walaupun belum terlihat tanda-tanda adanya gejala serangan hama dan penyakit tanaman. Hal demikian dilakukan oleh petani bukan pemilik dikarenakan adanya tindakan pencegahan (preventif), agar tidak terjadi serangan hama yang mengakibatkan penurunan hasil produksi, sehingga tidak akan mencapai keuntungan dalam berusahatani. Petani bukan pemilik lebih baik kehilangan biaya sedikit

lebih besar untuk membeli pestisida daripada mengambil resiko kegagalan atau menurunnya perolehan hasil produksi usahatani. 
Tabel 3. Rata-rata Jumlah Penggunaan Faktor Produksi Luas Lahan Produksi, Jumlah Pupuk Digunakan, Varietas dan Jumlah Benih, Jumlah Pestisida dan Penggunaan Tenaga Kerja

\begin{tabular}{|c|c|c|c|c|c|}
\hline \multirow{3}{*}{ Faktor Produksi } & \multirow{3}{*}{ Satuan } & \multicolumn{4}{|c|}{ Status Penguasaan Lahan } \\
\hline & & \multicolumn{2}{|c|}{ Milik Sendiri } & \multicolumn{2}{|c|}{ Bukan Milik Sendiri } \\
\hline & & Jumlah & $\%$ & Jumlah & $\%$ \\
\hline \multicolumn{6}{|l|}{ Luas Lahan Produksi } \\
\hline Luasan $1\left(<480 \mathrm{~m}^{2}\right)$ & Orang & 2 & 8 & 0 & 0 \\
\hline Luasan $2\left(480-3.684 \mathrm{~m}^{2}\right)$ & Orang & 21 & 84 & 22 & 88 \\
\hline Luasan $3\left(>3.684 \mathrm{~m}^{2}\right)$ & Orang & 2 & 8 & 3 & 12 \\
\hline Jumlah & Orang & 25 & 100 & 25 & 100 \\
\hline \multicolumn{6}{|l|}{ Jumlah Pupuk Digunakan } \\
\hline Urea & $\mathrm{kg} / \mathrm{ha}$ & 338,08 & 72 & 424,51 & 61 \\
\hline Phonska & $\mathrm{kg} / \mathrm{ha}$ & 87,31 & 19 & 172,72 & 25 \\
\hline TSP & $\mathrm{kg} / \mathrm{ha}$ & 43,68 & 9 & 100,40 & 14 \\
\hline Jumlah & $\mathrm{kg} / \mathrm{ha}$ & 469,07 & 100 & 697,63 & 100 \\
\hline \multicolumn{6}{|l|}{ Varietas Benih } \\
\hline IR-64 & Orang & 14 & 56 & 20 & 80 \\
\hline Mekongga & Orang & 5 & 20 & 2 & 8 \\
\hline Hibrida Mapan & Orang & 1 & 4 & 2 & 8 \\
\hline Benih Lain & Orang & 5 & 20 & 1 & 4 \\
\hline Jumlah & Orang & 25 & 100 & 25 & 100 \\
\hline \multicolumn{6}{|l|}{ Benih Digunakan } \\
\hline Jumlah & $\mathrm{kg} / \mathrm{ha}$ & 30,73 & & 32,14 & \\
\hline \multicolumn{6}{|l|}{ Pestisida } \\
\hline Jumlah & $\mathrm{ml} / \mathrm{ha}$ & 537,16 & & 709,76 & \\
\hline \multicolumn{6}{|l|}{ Penggunaan Tenaga Kerja } \\
\hline Persiapan & HOK & 5,08 & & 11,42 & \\
\hline Penanaman & $\mathrm{HOK}$ & 10,28 & & 20,26 & \\
\hline Perawatan & $\mathrm{HOK}$ & 6,15 & & 14,76 & \\
\hline Pemanenan & $\mathrm{HOK}$ & 13,82 & & 12,07 & \\
\hline Jumlah & $\mathrm{HOK}$ & 35,33 & & 58,51 & \\
\hline
\end{tabular}

Sumber : Diolah dari Data Primer, 2018.

Menurut Suratiyah, K (2006), tenaga kerja merupakan faktor penting dalam usahatani keluarga, khususnya tenaga kerja petani beserta anggota keluarganya. Pada usahatani padi sawah tadah hujan di Kabupaten Banyumas, penggunaan tenaga kerja antara petani pemilik dengan petani bukan pemilik memiliki perbedaan. Dalam kegiatan persiapan, penanaman dan perawatan usahatani, petani bukan pemilik menggunakan tenaga kerja yang jauh lebih banyak. Hal tersebut memberikan arti bahwa petani bukan pemilik melakukan kegiatan usahatani dengan lebih intensif. Pemberian waktu yang lebih banyak dan intensif ini bisa berasal dari dalam keluarga maupun dari luar keluarga dengan sistem upah. Dalam proses pemanenan, petani bukan pemilik membutuhkan jumlah HOK yang lebih sedikit dibandingkan dengan jumlah HOK yang dibutuhkan oleh petani pemilik. Proses langsung jual (tebasan) oleh petani bukan pemilik membuat kebutuhan HOK yang lebih sedikit jika dibandingkan dengan petani pemilik yang memanen sendiri dan dibawa ke rumah untuk disimpan sebagai stok persediaan. 


\section{Pengaruh Status Penguasaan Lahan Terhadap Produksi Padi Sawah Tadah Hujan}

Perbedaan status penguasaan lahan padi sawah tadah hujan ternyata menentukan tingkat keragaman usahatani dan dorongan yang berbeda antara petani pemilik dan petani bukan pemilik di Kabupaten Banyumas. Pada umumnya, petani bukan pemilik menggarap lahan persawahan tadah hujan karena dorongan ekonomi yang lebih kuat dibandingkan dengan petani pemilik. Petani bukan pemilik berusaha mendapatkan lahan sawah tadah hujan melalui berbagai cara, seperti menyewa, menyakap (bagi hasil), dan sebagainya. Hal tersebut dilakukan semata-mata hanya agar petani mendapatkan lahan sawah untuk digarap dan diusahakan secara intensif, sehingga mendapatkan hasil produksi dan pendapatan yang tinggi. Dalam menyewa lahan misalkan, petani bukan pemilik rela menyewa lahan persawahan sebesar Rp. 8 juta per ha/tahun. Harga sewa sebesar itu memang lebih kecil jika dibandingkan dengan harga sewa lahan pertanian di lahan sawah irigasi di Kabupaten Banyumas yang mencapai Rp. 12 juta per ha/tahun, namun harga tersebut sudah menjadi harga sewa umum untuk lahan sawah tadah hujan.

Dorongan yang besar untuk berusahatani mengakibatkan petani bukan pemilik menggunakan faktor produksi yang relatif lebih banyak dibandingkan dengan petani pemilik lahan. Petani bukan pemilik menggunakan pupuk lebih besar 48 persen dan rata-rata jumlah benih yang disemai lebih besar $2 \mathrm{~kg} / \mathrm{ha}$ dibandingkan dengan petani pemilik. Hal tersebut untuk menjamin agar budidaya tanaman padi yang diusahakan akan berjalan dengan baik. Dalam penggunaan pestisida, petani bukan pemilik menggunakan pestisida 32 persen lebih banyak dibandingkan dengan petani pemilik. Petani bukan pemilik lebih baik kehilangan biaya sedikit lebih besar untuk membeli pestisida daripada mengambil resiko kegagalan atau berkurangnya hasil produksi usahatani yang lebih banyak. Dalam penggunaan tenaga kerja, petani bukan pemilik membutuhkan jumlah HOK 2 kali lipat lebih besar jika dibandingkan dengan HOK yang dibutuhkan petani pemilik. Keadaan demikian sangat beralasan, petani bukan pemilik harus lebih intensif dalam pengelolaan usahatani karena petani bukan pemilik masih harus menanggung beban biaya sewa maupun biaya bagi hasil.

Penggunaan jumlah faktor produksi dan tingkat intensifikasi usahatani yang berbeda menjadi faktor utama perbedaan hasil produksi yang diperoleh antara petani pemilik dengan petani bukan pemilik pada sawah tadah hujan di Kabupaten Banyumas. Hasil analisis perbedaan jumlah produksi menggunakan uji One-way ANOVA dapat dilihat pada Tabel 4.

Pengujian hipotesis dalam penelitian ini menggunakan One-way ANOVA untuk menguji apakah ada perbedaan nyata produksi sawah tadah hujan antara status penguasaan lahan hak milik dengan status penguasaan lahan bukan milik. Berdasarkan uji Oneway ANOVA diketahui bahwa F-hitung (= 
$4,82)$ lebih besar dari F-tabel $(=4,04)$, ini artinya $\mathrm{H}_{0}$ ditolak dan $\mathrm{H}_{1}$ diterima. Hasil analisis tersebut artinya rata-rata produksi padi sawah tadah hujan di Kabupaten Banyumas menunjukkan perbedaan yang nyata dengan tingkat signifikansi $5 \%$ (P-value $<0,05)$ antara yang digarap oleh petani pemilik (status penguasaan lahan hak milik) dengan petani bukan pemilik (status penguasaan lahan bukan hak milik). Lahan persawahan tadah hujan yang digarap oleh petani bukan pemilik menghasilkan rata-rata jumlah produksi padi yang lebih tinggi $(943,81 \mathrm{~kg})$ dibandingkan dengan rata-rata jumlah produksi padi sawah tadah hujan yang digarap oleh petani pemilik (639,86 kg).

Pada dasarnya jumlah hasil produksi yang lebih tinggi dari petani bukan pemilik dibandingkan dengan petani pemilik sangatlah beralasan mengingat proses berusahatani yang lebih intensif dilakukan oleh petani bukan pemilik.

Tabel 4. Hasil Analisis Uji One-way ANOVA

\section{SUMMARY}

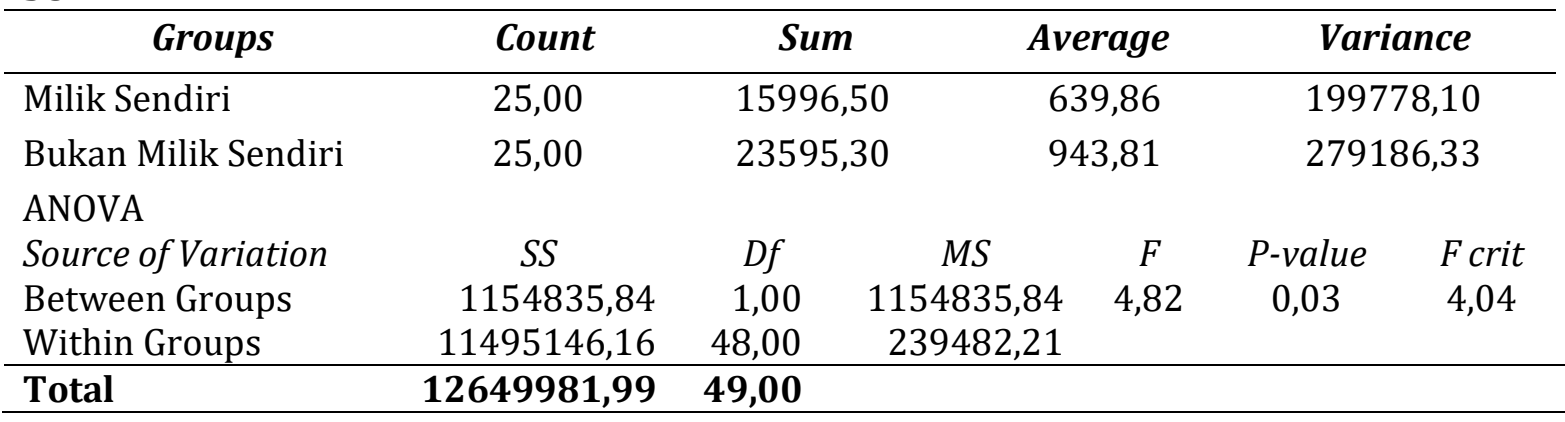

Sumber : Diolah dari Data Primer, 2018.

Selain itu petani bukan pemilik masih harus menanggung biaya sewa ataupun bagi hasil setelah panen dilakukan, sehingga petani bukan pemilik mempunyai motivasi ekonomi yang kuat untuk mendapatkan hasil produksi dan pendapatan usahatani yang lebih besar.

Perbedaan jumlah produksi padi sawah tadah hujan yang dipengaruhi status penguasaan lahan dengan hasil demikian tersebut merupakan hasil produksi dalam jangka pendek. Namun apabila hasil produksi padi sawah tadah hujan yang dipengaruhi status

penguasaan lahan dilihat dalam jangka panjang, tentu akan menjadi kajian yang menarik dan dimungkinkan mendapatkan hasil yang berbeda. Hal tersebut dikarenakan tidak hanya ditentukan oleh pengaruh penggunaan faktor produksi saja, tapi aspek keberlanjutan dan konservasi lahan juga perlu diperhitungkan.

\section{SIMPULAN}

Analisis varians satu arah (One-way ANOVA) menjelaskan bahwa rata-rata hasil produksi padi sawah tadah hujan di Kabupaten Banyumas menunjukkan perbedaan yang signifikan antara petani pemilik lahan dengan petani bukan pemilik lahan. Dengan luas lahan produksi yang relatif sama, petani bukan pemilik lahan mendapatkan rata-rata hasil produksi yang jauh lebih besar 
daripada rata-rata hasil produksi petani pemilik lahan sawah tadah hujan di Kabupaten Banyumas. Petani bukan pemilik lahan cenderung lebih intensif dalam berusahatani dibandingkan dengan petani pemilik lahan. Petani bukan pemilik lahan menggunakan pupuk Urea, Phonska dan TSP, benih padi, pestisida dan jumlah tenaga kerja yang lebih besar jika dibandingkan dengan penggunaan faktor produksi petani pemilik lahan.

\section{DAFTAR PUSTAKA}

BPS Kabupaten Banyumas (2011). Banyumas Dalam Angka 2011. ISSN : 0214-4331.

Damayanti, L (2013). Faktor-faktor yang Mempengaruhi Produksi, Pendapatan dan Kesempatan Kerja pada Usahatani Padi Sawah di Daerah Irigasi Parigi Moutong. Jurnal Sosial Ekonomi Pertanian dan Agribisnis (SEPA) : Vol. 9, No. 2, Februari 2013 : 249-259.

Eliyatiningsih dan Mayasari, F (2019). Efisiensi Penggunaan Faktor Produksi pada Usahatani Cabai Merah di Kecamatan Wuluhan Kabupaten Jember. Jurnal Agrica Uurnal Agribisnis Sumatera Utara). Vol 12 No. $1: 7$ - 16, April 2019

Gomez, KA. dan Gomez, AA. .1995. Prosedur Statisti untuk Penelitian Pertanian. Edisi Kedua. Penerbit Universitas Indonesia (UI-Press). ISBN : 979-456139-8.

Kay, Ronald D., dkk (2004). Farm Management. Fifth Edition. McGrawHill Comanies, Inc. New York.
Kristono, RJ dan Nadapdap, HJ (2019). Karakteristik Petani dan Orientasi Pasar sebagai Pengaruh Petani Krisan Melakukan Proses Pasca Panen. AGRILAND Jurnal Ilmu Pertanian, Vol 7 No. 2: 159-167. Juli-Desember 2019.

Manatar, MP. dkk (2017). Pengaruh Status Penguasaan Lahan Terhadap Pendapatan Petani Padi di Desa Tumani, Kecamatan Maesaan, Kabupaten Minahasa Selatan. Jurnal Agri-Sosioekonmomi Unsrat, ISSN 1907-4298, Volume 13 Nomor 1, Januari $2017: 55-64$.

Mudakir, B (2011). Produktivitas Lahan dan Distribusi Pendapatan Berdasarkan Status Penguasaan Lahan pada Usahatani Padi (Kasus di Kabupaten Kendal, Propinsi Jawa Tengah). Jurnal Dinamika Ekonomi Pembangunan, Vol 1 No. 1. Juli 2011.

Neonbota SL dan Kune, SJ, .2016. Faktorfaktor yang Mempengaruhi Usahatani Padi Sawah di Desa Haekto Kecamatan Noemuti Timur. Jurnal Agribisnis Lahan Kering. Agrimor Vol 1 No. 3 : Hal 32-35. ISSN 2502-1710.

Novia, RA 2012. Analisis Produksi, Pendapatan dan Ketahanan Pangan Rumah Tangga Tani Padi di Kabupaten Banyumas. Sekolah Pascasarana S2 Ekonomi Pertanian UGM. Yogyakarta.

Suratiyah, K .2006. Ilmu Usahatani. Penebar Swadaya. Jakarta.

Tahir, AG .2011. Analisis Risiko Produksi Usahatani Kedelai pada Berbagai Tipe Lahan di Sulawesi Selatan. Jurnal Sosial Ekonomi Pertanian, Volume 8, Nomor 1, Februari 2011.

Winarso, B. 2012. Dinamika Pola Penguasaan Lahan Sawah di Wilayah Pedesaan di Indonesia. Jurnal Penelitian Pertanian Terapan Vol. 12 (3) : 137 - 149. ISSN 1410 - 5020. 